\title{
Kesaksian Non Muslim dalam Perkara Perceraian menurut Pendapat Hakim di Pengadilan Agama Bandung
}

\author{
Ahmad Nabil Atoilah \\ Institut Agama Islam Darussalam (IAID) Ciamis, Jawa Barat \\ Email: ahmad.nabilatoillah@gmail.com \\ Bayu Alif Ahmad Yasin \\ Institut Agama Islam Darussalam (IAID) Ciamis, Jawa Barat
}

\begin{abstract}
ABSTRAK
Hukum Islam salah satu syarat menjadi seorang saksi adalah beragama Islam, tapi dalam Hukum Acara Peradilan Agama tidak mengatur tentang keislaman seorang saksi. Syarat beragama Islam tersebut mendapat tanggapan dari berbagai pihak terutama para hakim. Hakim mempunyai pendapat sendiri tentang saksi yang harus beragama Islam, dan itu berbeda seperti yang dirumuskan oleh para Ulama. Masalah kesaksian non muslim dalam perkara perceraian pendapat hakim mengenai kesaksian non muslim agar kesaksiannya diterima dan dinyatakan sah sebagaimana hukum Islam yang mengacu pada Undang-Undang No. 7 Tahun 1989, karena sejak diberlakukannya Undang-Undang tersebut Hukum Acara Peradilan Agama diperbolehkan memakai hukum Acara yang berlaku di Peradilan Umum sebagai Hukum Acaranya, yaitu HIR dan R.Bg.
\end{abstract}

\section{ABSTRACT}

Islamic law one of the requirements to be a witness is Islam, but in the Procedural Law of Religious Courts does not regulate the Islam of a witness. Terms of Islam is getting responses from various parties, especially the judges. The judge has his own opinion about the witness who must be Muslim, and that is different as formulated by the scholars. The issue of nonMuslim testimony in the case of divorce of judge opinion on the testimony of non-Muslims so that their testimony is accepted and declared valid as Islamic law which refers to Law no. 7 since 1989, since since the enactment of the Law, the Procedural Law of Religious Courts is allowed to apply the 
procedural law applicable in the General Courts as the Law of the Program, namely HIR and R.Bg.

Key Words: Testimony, witness, divorce, judge of religious court

\section{PENDAHULUAN}

Kajian tentang Peradilan Agama di Indonesia dan Peradilan pada umumnya terdapat istilah khusus diantaranya Peradilan dan Pengadilan.Peradilan merupakan salah satu pranata dalam memenuhi hajat hidup masyarakat dalam penegakan hukum dan keadilan, yang mengacu pada hukum yang berlaku. Sedangkan Pengadilan merupakan suatu organisasi yang menyelenggarakan penegakan hukum dan keadilan tersebut.

Dengan kata lain, Peradilan Agama dapat dirumuskan sebagai kekuasaan Negara dalam menerima, memeriksa, mengadili, memutus dan menyelesaikan perkara-perkara tertentuantara orang-orang yang beragama Islam untuk menegakkan hukum dan keadilan. Yang dimaksud dengan kekuasaan Negara adalah kekuasaan kehakiman. Sedangkan yang dimaksud perkara-perkara tertentu adalah perkara dalam bidang Perkawinan, kewarisan, wasiat, hibah, waqaf, dan shadaqah yang dilaksanakan dalam hukum Islam (Cik Hasan Bisri, 1997:36).

Salah satu kewenangan dari Pengadilan Agama adalah memeriksa, memutus, dan menyelesaikan perkara-perkara di tingkat pertama antara orang-orang yang beragama Islam di bidang perkawinan dan dalam hal ini adalah masalah perceraian. Perceraian baru dapat terjadi, jika ada alasanalasan tertentu dan tidak memungkinkan mereka hidup rukun, damai, aman, tentram, kekal, dan bahagia dalam satu rumah tangga. Hal ini harus dilakukan berdasarkan keputusan Pengadilan Agama, demi kepastian hukum yang akan terjadi.

Perkawinan merupakan sunnatullah yang berlaku untuk semua makhluk-Nya yang ada di bumi. Perkawinan merupakan cara yang dipilih Allah sebagai jalan bagi manusia untuk beranak pinak, berkembang biak dan melestarikan hidupnya. Sebagaimana firman Allah dalam surat Ar-Rum ayat 21:

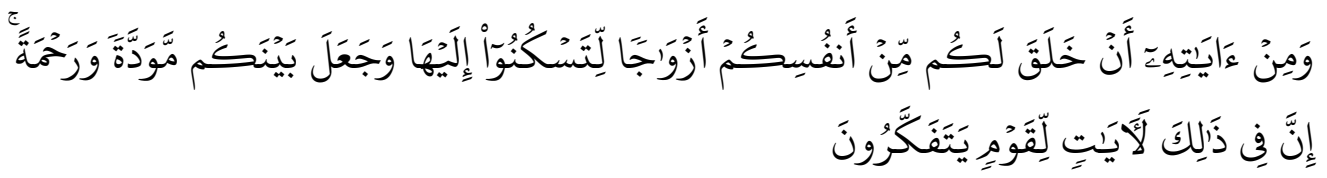

Dan di antara tanda-tanda kekuasaan-Nya ialah Dia menciptakan untukmu isteri-isteri dari jenismu sendiri, supaya kamu cenderung dan merasa tenteram kepadanya, dan dijadikan-Nya diantaramu rasa kasih 
dan sayang. Sesungguhnya pada yang demikian itu benar-benar terdapat tanda-tanda bagi kaum yang berfikir (Q.S. Ar-Rum, 30:21).

Semua orang menginginkan agar dalamperkawinannya mampu mewujudkan kehidupan rumah tangga yang sakinah, mawaddah, dan rahmah. Untuk mewujudkan tujuan tersebut tidaklah mudah, perkawinan harus dijaga sedemikian rupa agar tidak hancur di tengah jalan yang menyebabkan terjadinya perceraian.

Kata perceraian dalam keluarga seakan merupakan bencana bagi sebuah mahligai rumah tangga. Setiap orang tentu tidak menginginkan perceraian terjadi dalam kehidupan mereka, namun fenomena perceraian semakin marak belakangan ini. Banyak alasan yang membuat suami istri mengambil jalan perceraian seperti ketidakcocokan, disharmoni akibat faktor ekonomi dan lain-lain.

Perceraian merupakan putusnya hubungan antara pasangan suami istri sehingga implikasi yang ditimbulkannya akan berlaku pada pasangan suami istri yang melakukan perceraian. Bagi masyarakat muslim Indonesia untuk melakukan perceraian harus mengajukan ke Pengadilan Agama. Untuk mengajukan perceraian ke Pengadilan bukanlah hal yang mudah, tetapi ada beberapa proses yang harus dilalui.

Alasan yang dapat dijadikan dasar melakukan perceraian diatur dalam penjelasan Pasal 39 ayat (2) Undang-Undang No. 1 tahun 1974 jo Pasal 19 Peraturan Pemerintah No. 9 Tahun 1975 jo Pasal 116 Kompilasi Hukum Islam(KHI), yang menyatakan bahwa perceraian dapat terjadi karena alasan-alasan:

1) Salah satu pihak berbuat zina atau menjadi pemabuk, pemadat, penjudi, dan lain sebagainya yang sukar disembuhkan;

2) Salah satu pihak meninggalkan pihak lain selama 2 (dua) tahun berturut-turut tanpa izin dari pihak lain dan tanpa alasan yang tidak sah atau karena hal lain di luar kemampuannya;

3) Salah satu pihak mendapat hukuman penjara 5 (lima) tahun atau hukuman yang lebih berat setelah perkawinan berlangsung;

4) Salah satu pihak melakukan kekejaman atau penganiayaan berat yang membahayakan pihak lain;

5) Salah satu pihak mendapat cacat badan;

6) Antara suami dan isteri terus menerus terjadi perselisihan dan pertengkaran dan tidak ada harapan akan hidup rukun lagi dalam rumah tangga;

7) Suami melanggar taklik-talak; 
8) Peralihan Agama atau murtad yang menyebabkan terjadinya ketidak rukunan dalam rumah tangga.

Setiap sengketa yang diajukan di muka pengadilan setidak-tidaknya terdapat dua pihak yang berperkara, yaitu pihak penggugat dan tergugat. Pihak penggugat adalah pihak yang mengajukan gugatan, sedangkan pihak tergugat adalah pihak yang mempertahankan kenyataan yang berlaku dan melawan gugatan itu (Anshoruddin, 2004:41).

Penggugat adalah orang yang tidak dapat dipaksa untuk meneruskan gugatannya, apabila dia tidak mau meneruskannya. Sedangkan tergugat adalah orang yang dapat dipaksa untuk menerima gugatan. Oleh sebab itu, membuktikan kebenaran gugatan adalah satu hal yang sangat dipentingkan oleh pengadilan, maka hakim harus mengetahui siapa yang wajib membuktikan kebenaran gugatan itu (Anshoruddin, 2004:42).

Dalam hukum acara peradilan Islam bahwa untuk membuktikan kebenaran gugatan adalah tugas dari penggugat, sebab menurut asal segala urusan itu diambil yang lahirnya. Maka wajib atas orang yang mengemukakan gugatannya atas sesuatu yang lahir, untuk membuktikan kebenaran gugatannya itu (Anshoruddin, 2004:42).

Alat-alat bukti dalam HIR (Herziene Indonesische Reglement) pada pasal 164, Rbg (Rechtsreglement Voor De Buitengewesten) pada pasal 284, BW (Burgerlijke Wetboek) pada pasal 1866 sebagai berikut:

1) Bukti Surat

2) Bukti Saksi

3) Sangka

4) Pengakuan

5) Sumpah

Dalam hal mengadili sengketa perceraian, salah satu tugas hakim dalam proses pemeriksaan perceraian sebelum suatu perkara diputus harus benar-benar meyakini dengan pasti apakah saksi yang diperiksa dalam persidangan telah memahami dengan baik apa yang disaksikannya itu sehingga hakim dapat dengan mudah memperikan pertimbangan hukum di dalam menjatuhkan putusan. Kedudukan saksi dalam perkara perceraian sangat penting bagi hakim dalam mempertimbangkan putusan yang akan dijatuhkan.

Menurut hukum acara perdata supaya saksi-saksi yang diajukan oleh para pihak dapat didengar sebagai alat bukti, maka saksi harus memenuhi syarat materiil, yaitu: keterangan yang diberikan mengenai peristiwa yang dialami, didengar, dan dilihat sendiri, keterangan yang diberikan saksi mempunyai sumber pengetahuan yang jelas sebagaimana pasal 308 ayat (1) 
R.Bg, dan keterangan yang diberikan saksi saling bersesuaian satu sama lain atau dengan alat bukti lain (Chatib Rasyid, 2009:111-112).

Selain syarat materiil saksi juga harus memenuhi syarat-syarat formil, yaitu: memberi keterangan di depan persidangan, bukan yang dilarang untuk didengar sebagai saksi, bagi kelompok yang berhak mengundurkan diri sebagai saksi menyatakan kesediaannya untuk diperiksa sebagai saksi dan mengucapkan sumpah menurut Agama yang dianut (Abdul Manan, 2006:250).

Undang-Undang Hukum Perdata Burgerlijk Wetboek (BW) dan Herziene Inlandsch Reglement (HIR) menyatakan bahwa saksi non Muslim bisa diterima kesaksiannya tergantung kepada hakim yang memutuskan perkara. Sedangakan menurut hukum Islam saksi yang dapat diterima kesaksiannya adalah yang memenuhi syarat, dimana syarat tersebut merupakan suatu kewajiban yang harus dimiliki seseorang untuk memberikan kesaksian, sehingga apabila tidak terpenuhinya syarat-syarat maka kesaksian seseorang tidak dapat diterima. Adapun syarat-syaratnya antara lain: Islam, baligh, berakal, merdeka, dan adil.

Kemudian menurut para ulama (Imam Malik, Imam Syafi'I, dan Imam Ahmad) berpendapat bahwa kesaksian non muslim tidak dapat diterima secara mutlak. Sebagaimana Firman Allah dalam surat Ath-Thalaq ayat 2:

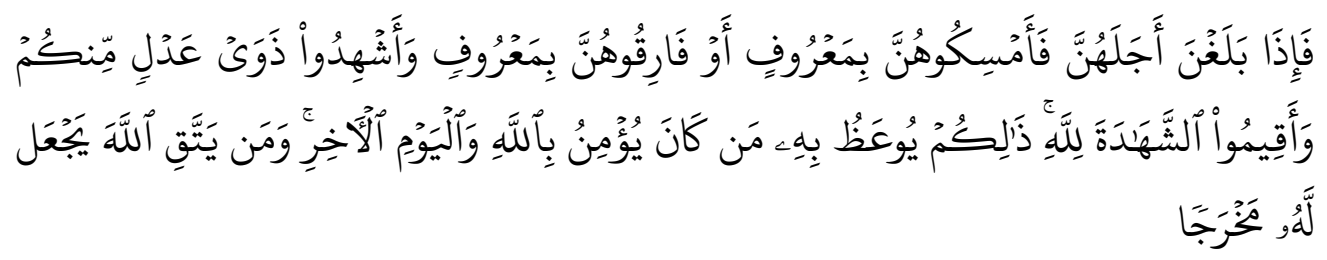

Apabila mereka telah mendekati akhir iddahnya, maka rujukilah mereka dengan baik atau lepaskanlah mereka dengan baik dan persaksikanlah dengan dua orang saksi yang adil di antara kamu dan hendaklah kamu tegakkan kesaksian itu karena Allah.Demikianlah diberi pengajaran dengan itu orang yang beriman kepada Allah dan hari akhirat.Barangsiapa bertakwa kepada Allah niscaya Dia akan Mengadakan baginya jalan keluar" (Q.S. Ath-Thalaq, 65: 2).

Menurut Quraish Shihab dalam kitab tafsir al-Misbah, maksud dari kalimat dan persaksikanlah untuk perceraian itu dengan dua orang saksi yang adil dari kelompok kamu yakni kaum muslimin, agar tidak timbul rumor, tidak juga kecurigaan dan agar menjadi jelas kedudukan istri seandainya suami tiba-tiba meninggal dunia (M. Quraish Shihab, 2002:289).

Kesaksian non muslim terhadap orang Islam menurut kesepakatan fuqoha tidak diterima kesaksiannya. Sedangkan kesaksian orang Islam 
terhadap non muslim ada dua pendapat. Menurut ulama Hanafi boleh dan menurut fuqoha lainnya tidak boleh (Anshoruddin, 2004:80).

Pada Putusan Nomor1466/Pdt.G/2015/PA.Bdg tentang Saksi Non Muslim menimbang bahwa Majelis Hakim telah melakukan perdamaian kepada para pihak, akan tetapi tidak berhasil. Lalu dibacakan surat gugatan penggugat yang isinya tetap dipertahankan oleh penggugat;

Dalam berita acara persidangan Nomor 1466/Pdt.G/2015/PA.Bdg selanjutnya dipanggil masuk dan menghadap saksi termohon yang kedua, yang atas pertanyaan Majelis mengaku bernama: SAKSI, umur 59 tahun, Agama Katolik, pekerjaan swasta, tempat kediaman di Kecamatan Kemayoran Kota Jakarta. Kemudian saksi tersebut bersumpah menurut tata cara Agamanya, bahwa ia akan menerangkan yang sebenarnya dan tidak lain kecuali yang sebenarnya.

Sebagai seorang hakim yang harus tunduk kepada Undang-Undang yang berlaku, apalagi dalam lingkup Peradilan Agama yang tidak sepenuhnya menggunakan Al-Quran, Hadits, dan kitab-kitab fikih sebagai landasan hukum dalam mengambil keputusan, tentunya seorang hakim memiliki kewenangan khusus untuk menerima seorang saksi untuk dijadikan alat bukti yang dianggap sah dan dapat diterima keterangannya.

Setelah diberlakukannya Undang-Undang No. 7 Tahun 1989 tentang Peradilan Agama dalam pasal 54 Undang-Undang tersebut menyatakan bahwa: "Hukum Acara yang berlaku pada Pengadilan dalam lingkungan Peradilan Agama adalah Hukum Acara Perdata yang berlaku pada Pengadilan dalam lingkungan Peradilan Umum, kecuali yang telah diatur secara khusus dalam Undang-Undang ini".

Dengan adanya Undang-Undang tersebut yang memuat khusus mengenai Peradilan Agama yang mana di dalamnya tidak mensyaratkan saksi harus beragama Islam dan tidak ada kriteria-kriteria khusus seperti para ulama tetapkan agar keterangan seorang saksi dikatakan sah dan dapat diterima. Selain itu Peradilan Agama adalah sebuah lembaga yang bisa dikatakan sebagai lembaga yang berbasis Islam, dan tentunya hakim-hakim di Peradilan Agama setidaknya memiliki latar belakang Agama.

Sebagai manusia, seorang hakim Peradilan Agama selain harus tunduk pada peraturan Undang-Undang, yaitu HIR dan R.Bg sebagai landasan hukum formil, hakim Peradilan Agama juga tidak bisa mengabaikan Al-Quran, As-Sunnah, dan kitab-kitab fikih sebagai salah satu landasan hukum materiil. Dalam mempertimbangkan kesaksian non muslim di dalam persidangan dapat diterima dan dikatakan sah baik dari Hukum Islam ataupun menurut Undang-Undang yang berlaku 


\section{KAJIAN TEORI}

\section{Konsep Pembuktian}

Menurut istilah bukti adalah suatu hal atau peristiwa dan sebagainya yang cukup untuk memperlihatkan kebenaran suatu hal atau peristiwa dan sebagainya. Secara etimologi pembuktian berasal dari kata "bukti", artinya sesuatu yang menyatakan kebenaran suatu peristiwa. Kata "bukti" jika mendapat awalan "pem" dan akhiran "an" maka mengandung arti proses, perbuatan, atau cara membuktikan. Adapun secara terminologi pembuktian berarti usaha untuk menunjukkan benar atau salahnya para pihak dalam sidang pengadilan.

Menurut Sobhi Mahmasoni menyatakan bahwa yang dimaksud dengan membuktikan suatu perkara adalah mengajukan alasan dan memberikan dalil sampai kepada batas yang meyakinkan. Adapun maksud dari "meyakinkan" adalah apa yang menjadi ketetapan atau keputusan atas dasar penelitian dan dalil-dalil itu (Asadulloh al-Faruq, 2009:31).

Pembuktian adalah meyakinkan hakim tentang kebenaran dalil atau dalil-dalil yang dikemukakan dalam suatu persengketaan. Dengan demikian pembuktian hanya diperlukan dalam persengketaan atau perkara dimuka hakim atau pengadilan.

Dalam perkara perdata pada umumnya pembuktian hanya diperlukan manakala dalil dibantah oleh pihak lawan. Tetapi berbeda dengan perkara perdata di Pengadilan Agama, khususnya mengenai perkara perceraian yang tidak sepenuhnya menempatkan pengakuan sebagai alat bukti yang tidak mengandung nilai sempurna dan mengikat, maka hubungan hukum dan atau fakta kejadian tidak dibantah oleh pihak lawan, penggugat/ pemohon tetap dibebankan untuk membuktikan gugatan (Chatib Rasyid, 2009:107).

R. Soepomo mendefinisikan pembuktian dengan memberikan dua kualifikasi, yaitu:

1) Pembuktian dalam arti luas, yaitu membenarkan hubungan hukum, misalnya apabila hakim mengabulkan tuntutan penggugat. Pengabulan ini mengandung arti bahwa hakim menarik kesimpulan apa yang dikemukakan oleh penggugat sebagai hubungan hukum antara penggugat dan tergugat adalah benar. Untuk itu membuktikan dalam arti luas berarti memperkuat kesimpulan hakim dengan syarat-syarat bukti yang sah.

2) Pembuktian dalam arti sempit, yaitu pembuktian yang hanya diperlukan manakala apa yang dikemukakan penggugat dibantah oleh tergugat (Soepomo, 1978:62-63). 
Sedangkan untuk definisi secara sederhananya menurut Asadulloh pembuktian merupakan tindakan memberi kepastian hukum kepada hakim tentang adanya peristiwa-peristiwa tertentu (Asadulloh al-Faruq, 2009:33).

Secara etimologis pembuktian dalam istilah Arab disebut $\mathrm{Al}$ Bayyinah, yang artinya satu yang menjelaskan. Hakim dalam memeriksa perkara harus berdasarkan pembuktian, dengan tujuan untuk meyakinkan hakim tentang kebenaran dalil-dalil yang dikemukakan dalam suatu persengketaan atau untuk memperkuat kesimpulan hakim dengan syaratsyarat bukti yang sah. Dengan demikian, pembuktian adalah segala sesuatu atau alat bukti yang dapat menampakan kebenaran di sidang peradilan dalam suatu perkara (Asadulloh al- Faruq, 2009:106).

Sebagaimana Pasal 1865 KUH Perdata yang berbunyi "Setiap orang yang mendalilkan bahwa ia mempunyai sesuatu hak, atau guna meneguhkan haknya sendiri maupun membantah suatu hak orang lain, menunjukkan pada suatu peristiwa, diwajibkan membuktikan adanya hak atau peristiwa tersebut" (Subekti, 2010:475).

Dalam pembuktiannya seseorang harus mampu mengajukan buktibukti yang otentik. Keharusan pembuktian ini didasarkan antara lain pada Firman Allah Surat Al-Baqarah ayat 282:

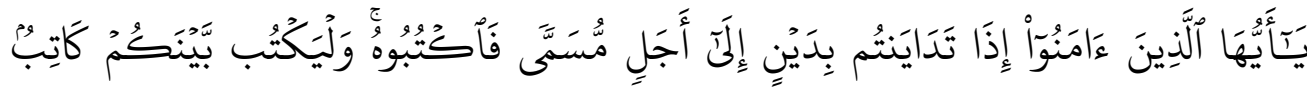



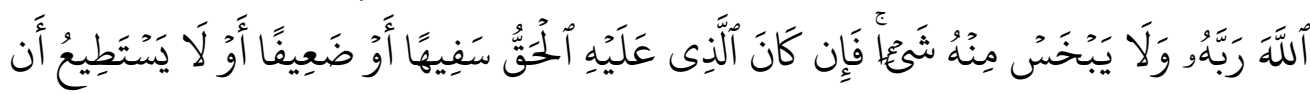

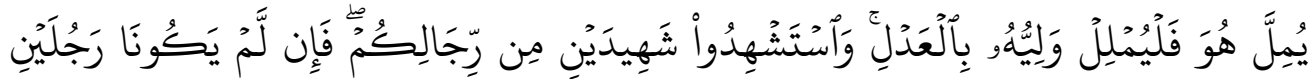

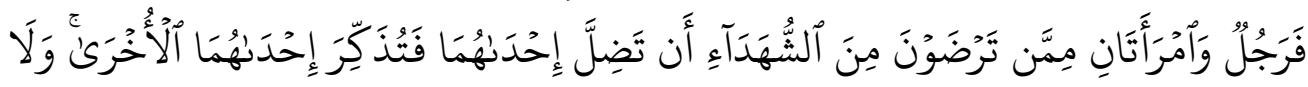

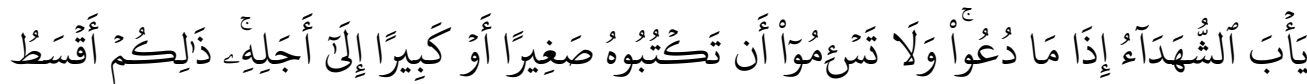

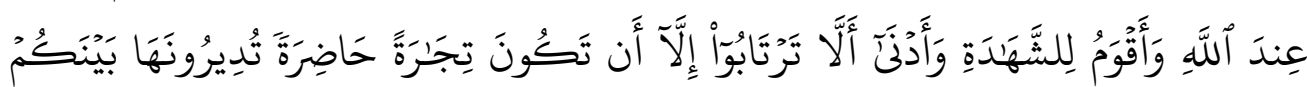

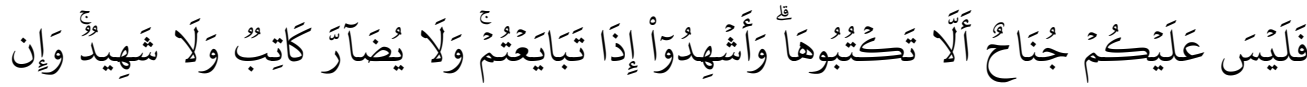

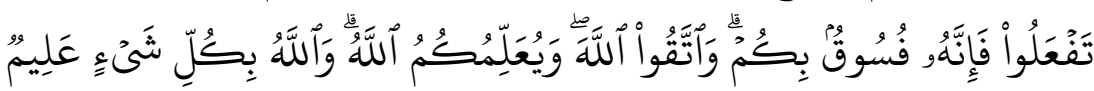

Dan persaksikanlah dengan dua orang saksi dari orang-orang lelaki (di antaramu). jika tak ada dua oang lelaki, maka (boleh) seorang lelaki dan dua orang perempuan dari saksi-saksi yang kamu ridhai, supaya jika seorang lupa maka yang seorang mengingatkannya. janganlah saksi-saksi itu enggan (memberi keterangan) apabila mereka dipanggil" (Q.S. AlBaqarah, 2:282). 
Firman Allah dalam Surat Al-Maidah ayat 106:

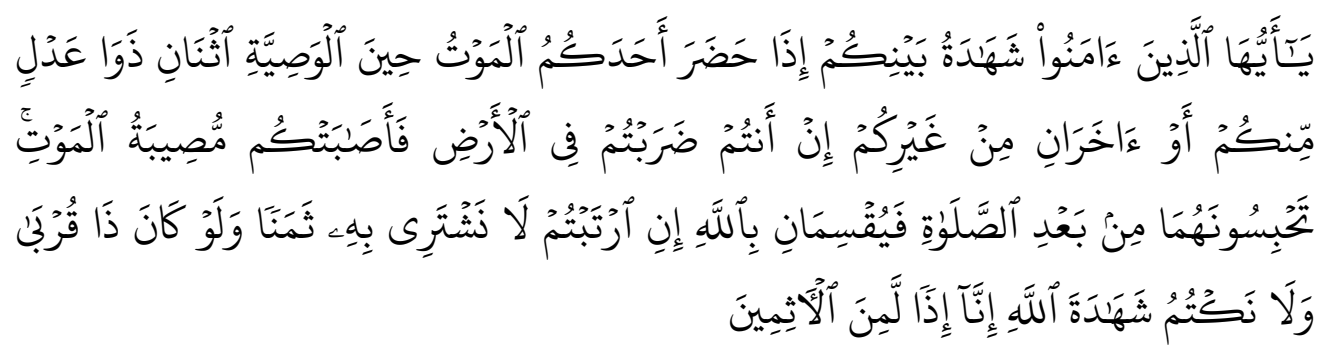

Hai orang-orang yang beriman, apabila salah seorang kamu menghadapi kematian, sedang Dia akan berwasiat, Maka hendaklah (wasiat itu) disaksikan oleh dua orang yang adil di antara kamu, atau dua orang yang berlainan agama dengan kamu" (Q.S. Al-Maidah, 5:106).

Ayat di atas mengandung makna bahwa bilamana seseorang sedang berperkara atau sedang mendapatkan permasalahan, maka para pihak harus mampu membuktikan hak-haknya dengan mengajukan saksi-saksi yang dipandang adil (Anshoruddin, 2004:35).

Setiap proses perkara yang penyelesaiannya melalui pengadilan pada asasnya diperlukan pembuktian baik itu terjadi dalam proses perkara perdata atau perkara pidana dengan cara mencari kebenaran melalui buktibukti yang turut member penerangan bagi hakim dalam mengambil putusan akhir.

Dalam hukum positif, perihal pembuktian mempunyai muatan unsur materiil dan formil. Hukum pembuktian materil mengatur tentang dapat tidaknya diterima pembuktian dengan alat-alat bukti tertentu di persidangan serta kekuatan pembuktiannya. Sedangkan hukum pembuktian formil mengatur tentang cara mengadakan pembuktian (Anshoruddin, 2004:40).

Dasar hukum pembuktian dalam hukum positif tercantum pada pasal 163 HIR, pasal 283 Rbg, dan pasal 1865 BW. Bunyi ketiga pasal tersebut pada hakikatnya adalah sama yakni:

Barangsiapa menyatakan ia mempunyai hak atau ia menyebutkan sesuatu perbuatan untuk menguatkan haknya itu, atau untuk membantah hak orang lain, maka orang itu harus membuktikan adanya hak atau adanya kejadian itu.

Perlunya pembuktian ini agar manusia tidak semaunya saja menuduh orang lain dengan tanpa adanya bukti yang menguatkan tuduhannya. Adanya kewajiban ini akan mengurungkan gugatan orangorang yang dusta, lemah dan gugatan yang asal gugat.

Ada sejumlah jenis alat bukti di peradilan, yaitu: 


\section{1) Menurut Hukum Islam}

Alat bukti artinya alat untuk menjadi pegangan hakim sebagai dasar dalam memutus suatu perkara, sehingga dengan berpegang kepada alat bukti tersebut dapat mengakhiri sengketa di antara mereka (Anshoruddin, 2004:55).

Dipandang dari segi pihak-pihak yang berperkara, alat bukti artinya alat atau upaya yang bisa dipergunakan oleh pihak-pihak yang berperkara untuk meyakinkan hakim di muka pengadilan. Dipandang dari segi pengadilan yang memeriksa perkara, alat bukti artinya alat atau upaya yang bisa dipergunakan oleh hakim untuk memutus perkara. Jadi alat bukti tersebut diperlukan oleh pencari keadilan maupun pengadilan (Roihan A. Rasyid, 1991:145).

Menurut Ibnu Qayyim Al- Jauziyyah alat bukti adalah bukti yang diajukan di depan pengadilan untuk menguatkan gugatan. Untuk memberikan dasar kepada hakim akan kebenaran peristiwa yang didalilkan para pihak yang dibebani pembuktian diwajibkan mengajukan alat-alat bukti untuk membuktikan peristiwa-peristiwa di muka persidangan (Anshoruddin, 2004:56).

Menurut Samir 'Aaliyah, alat-alat bukti itu ada enam dengan urutan sebagai berikut:
a) Pengakuan
b) Saksi
c) Sumpah
d) Qorinah
e) Bukti berdasarkan indikasi-indikasi yang tampak
f) Pengetahuan hakim (Anshoruddin, 2004:57).

Menurut Sayyid Sabiq, alat-alat bukti itu ada empat, dengan urutan sebagai berikut:
a) Pengakuan
b) Saksi
c) Sumpah
d) Surat resmi (Anshoruddin, 2004:58).

Menurut Nashr Fariid Waashil, alat-alat bukti itu ada sebelas, dengan urutan sebagai berikut:
a) Pengakuan
b) Saksi 
c) Sumpah

d) Pengembalian sumpah

e) Penolakan sumpah

f) Tulisan

g) Saksi ahli

h) Qorinah

i) Pendapat ahli

j) Pemeriksaan setempat

k) Permintaan keterangan orang yang bersengketa (Anshoruddin, 2004:59).

Dari berbagai pendapat ulama tersebut di atas nampak bahwa pendapat Nashr Fariid Waashil lebih banyak varian dalam menggambarkan alat-alat bukti dibanding dengan ulama lainnya.

2) Menurut Hukum Positif

Untuk membuktikan peristiwa-peristiwa di muka persidangan dilakukan dengan menggunakan alat-alat bukti. Dengan alat-alat bukti yang diajukan itu memberikan dasar kepada hakim akan kebenaran peristiwa yang didalilkan.

Dalam hukum acara perdata telah diatur alat-alat bukti yang dipergunakan di persidangan. Dengan demikian hakim sangat terikat oleh alat-alat bukti, sehingga dalam mejatuhkan putusannya, hakim wajib memberikan pertimbangan berdasarkan alat-alat bukti yang sah menurut undang-undang.

Alat-alat bukti menurut pasal $164 \mathrm{HIR} / 284$ RBg/1866 KUH Perdata adalah sebagai berikut:
a) Surat
b) Saksi
c) Persangkaan
d) Pengakuan
e) Sumpah

Bilamana diperlukan, tidak menutup kemungkinan untuk dilakukan pemeriksaan di tempat, dan penyelidikan orang ahli guna memvalidkan data yang diperlukan, sebagaimana dinyatakan dalam pasal 153 ayat (1) HIR yang berbunyi:

Jika ditimbang perlu atau ada faedahnya, maka ketua boleh mengangkat satu atau dua orang komisaris dari para dewan itu, yang dengan bantuan 
panitera pengadilan akan melihat keadaan tempat atau menjalankan pemeriksaan di tempat itu, yang dapat menjadi keterangan kepada hakim.

Juga disebutkan dalam pasal 154 HIR yang berbunyi:

Jika pengadilan negeri menimbang, bahwa perkara itu dapat lebih terang, jika diperiksa atau dilihat oleh orang ahli, maka dapatlah ia mengangkat ahli itu, baik atas permintaan kedua pihak, maupun karena jabatannya.

Undang-Undang Nomor 7 Tahun 1989 yang mengalami perubahan pertama yaitu Undang-Undang Nomor 3 Tahun 2006 dan kemudian mengalami perubahan kedua yaitu Undang-Undang Nomor 50 Tahun 2008 selain mengatur tentang susunan dan kekuasaan Peradilan Agama di dalamnya juga sekaligus mengatur tentang hukum acara.

Tidak semua hukum acara peradilan agama diatur secara lengkap dalam Undang-Undang yang bersangkutan, hal tersebut bisa dilihat pada Undang-Undang Nomor 7 Tahun 1989 yang mengalami dua kali perubahan yaitu Undang-Undang Nomor 3 Tahun 2006 dan Undang-Undang Nomor 50 Tahun 2008 di dalam pasal 54 yang menentukan sebagai berikut:

Hukum Acara yang berlaku pada Pengadilan dalam lingkungan Peradilan Agama adalah Hukum Acara Perdata yang berlaku pada Pengadilan dalam lingkungan Peradilan Umum, kecuali yang telah ditulis secara khusus dalam Undang-Undang ini".

Ketentuan tersebut menunjuk kepada Hukum Acara yang berlaku pada Pengadilan Negeri yaitu Hukum Acara Perdata yang diatur dalam HIR untuk daerah Jawa dan Madura, dan R.Bg untuk daerah seberang. Pengadilan Agama memberlakukan HIR dan R.Bg sepanjang belum diatur dalam Undang-Undang Peradilan Agama, artinya sepanjang diatur dalam Undang-Undang Peradilan Agama, Maka (Herziene Indonesische Reglement) HIR dan (Rechtsreglement Voor De Buitengewesten) R.Bg dapat dikesampingkan.

Konsep Saksi

Kata saksi dalam bahasa Arab adalah "syaahid" atau "syahiid" yaitu orang yang mengetahui dan menerangkan apa yang diketahuinya. Kata jama'nya adalah "asyhaad" dan "syuhuud". Kata "syahid"jama'nya ialah "syuhadaa". Masdarnya adalah asy-syahaadah yang artinya kabar yang pasti. Saksi adalah sebuah kata benda dalam bahasa Indonesia yang berarti orang yang melihat atau mengetahui (WJS. Poerwadarminta, 1976:875).

Pengertian saksi adalah orang yang mempertanggungjawabkan, karena dia menyaksikan sesuatu (peristiwa) yang orang lain tidak menyaksikannya. Sedangkan kesaksian adalah istilah mengenai pemberitahuan seseorang yang benar di depan Pengadilan dengan ucapan 
kesaksian untuk menetapkan suatu hak terhadap orang lain (Abd. Rahman Umar, 1986:35).

Kesaksian dalam Hukum Acara Islam dikenal dengan istilah AsySyahadah. Menurut bahasa, asy-syahadah memiliki pengertian sebagai berikut:

a) Pernyataan atau pemberitaan yang pasti.

b) Ucapan yang keluar dari pengetahuan yang diperoleh dengan penyaksian langsung.

c) Mengetahui sesuatu secara pasti, mengalami, dan melihatnya.

Menurut syara' kesaksian adalah pemberitaan yang pasti, yaitu ucapan yang keluar dan diperoleh dengan penyaksian langsung atau dari pengetahuan yang diperoleh dari orang lain karena berita-berita telah tersebar. Dalam masalah perdata, kesaksian memiliki definisi lebih khusus, yaitu pemberitaan mengenai hak seseorang atas orang lain dengan ucapan kesaksian di depan sidang pengadilan yang diperoleh dari penyaksian langsung, bukan karena dugaan atau perkiraan (Asadulloh Al-Faruq, 2009:45).

Menurut Muhammad Salam Madzkur, persaksian adalah suatu ungkapan tentang berita yang benar di sidang pengadilan dengan menggunakan lafadz syahadah (ucapan kesaksian) untuk menetapkan suatu hal atas diri orang lain. Dalam pengertian tersebut dikatakan yang menyangkut atas diri orang lain, sebab bila yang menyangkut atas diri sendiri bukanlah kesaksian, melainkan ikrar (Asadulloh Al-Faruq, 2009:45).

Ahmad Ad-Daur mendefinisikan kesaksian sebagai penyampaian perkara yang sebenarnya untuk membuktikan sebuah kebenaran dengan mengucapkan lafal-lafal kesaksian dihadapan sidang pengadilan (Asadulloh Al-Faruq, 2009:46).

Dikatakan pula bahwa kesaksian berasal dari kata i'laam (pemberitahuan). Firman Allah dalam surat Ali-Imran ayat 18:

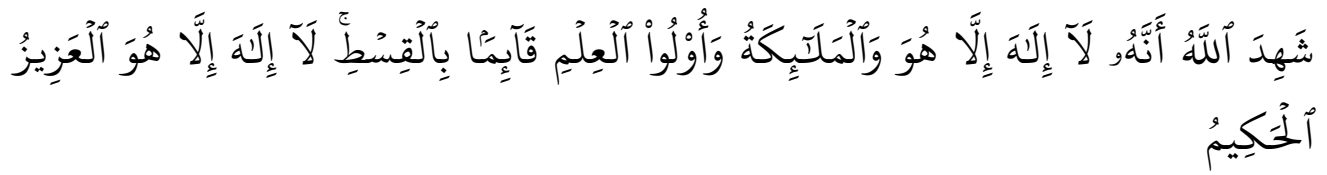

Allah menyatakan bahwasanya tidak ada Tuhan melainkan Dia (yang berhak disembah), yang menegakkan keadilan. Para Malaikat dan orangorang yang berilmu (juga menyatakan yang demikian itu).tak ada Tuhan melainkan Dia (yang berhak disembah), yang Maha Perkasa lagi Maha Bijaksana" (Q.S. Ali-Imran, 3:18). 
Di sini arti dari kata syahida adalah 'alima (mengetahui). Syahid adalah orang yang membawa kesaksian dan menyampaikannya, sebab dia menyaksikan apayang tidak diketahui orang lain (Sayyid Sabiq, 1989:55).

Menurut istilah jumhur ulama, sinonim kata al-Bayyinah adalah syahadah yang artinya kesaksian. Pengertian al-Bayyinah dalam Al-Quran, As-Sunnah dan perkataan para sahabat Nabi saw adalah nama bagi setiap sesuatu yang dapat menyatakan dan mengungkapkan kebenaran (Abd. Rahman Umar, 1986:38).

Menurut Hukum Positif, saksi ialah orang yang memberikan keterangan di muka sidang, dengan memenuhi syarat-syarat tertentu, tentang suatu peristiwa atau keadaan yang ia lihat, dengar dan ia alami sendiri, sebagai bukti terjadinya peristiwa atau keadaan tersebut. Mengenai alat bukti saksi ini diatur dalam pasal 168- 172 dan pasal 165-179 R.Bg (Mukti Arto, 2005:165).

Menurut Sudikno Mertokusumo saksi adalah kepastian yang diberikan kepada hakim di persidangan tentang peristiwa yang disengketakan dengan jalan pemberitahuan secara lisan dan pribadi oleh orang yang bukan salah satu pihak dalam perkara yang dipanggil di persidangan (Sudikno Mertokusumo, 1998:112).

Pada dasarnya pembuktian dengan saksi baru diperlukan apabila bukti dengan surat atau tulisan tidak ada atau kurang lengkap untuk mendukung atau menguatkan kebenaran dalil-dalil yang menjadi dasar pendiriannya para pihak. Saksi-saksi ada yang secara kebetulan melihat atau mengalami sendiri peristiwa atau kejasian yang harus dibuktikan kebenarannya di muka sidang pengadilan, ada juga saksi-saksi itu sengaja diminta untuk datang langsung menyaksikan suatu peristiwa atau perbuatan hukum yang sedang terjadi.

Tentang keterangan saksi yang dapat dijadikan alat bukti yang sah menurut hukum sebagaimana yang disebutkan dalam pasal 164 HIR dan Pasal 284 R.Bg harus terbatas pada peristiwa-peristiwa yang dialami, dilihat atau didengar sendiri, dan harus pula disertai alasan-alasan bagaimana diketahuinya peristiwa yang diterangkan oleh saksi-saksi tersebut. Pendapat dan kesimpulan yang diperoleh dengan jalan menggunakan buah pikiran kesaksian sebagaimana pasal 171 HIR dan pasal 308 RBg. Jadi saksi-saksi itu adalah orang-orang yang mengalami, mendengar, merasakan dan melihat sendiri suatu peristiwa atau kejadian-kejadian dalam perkara yang sedang disengketakan (Abdul Manan, 2006:248-249).

Dalam pasal 1895 KUH Perdata disebutkan bahwa "pembuktian dengan saksi-saksi diperbolehkan dalam segala hal yang tidak dikecualikan oleh undang-undang". Menurut pasal 1902 KUH Perdata, dalam suatu peristiwa atau hubungan hukum menurut undang-undang hanya dapat dibuktikan dengan tulisan atau akta, namun alat bukti tersebut hanya 
berkualitas sebagai permulaan pembuktian tulisan, penyempurnaan pembuktiannya dapat ditambah dengan saksi (Yahya Harahap, 2008:642).

Syarat-syarat Menjadi Saksi

Menurut hukum Islam syarat-syarat saksi yang dapat diterima kesaksiannya adalah sebagai berikut:

1) Baligh, maka tidak diterima kesaksian anak kecil sebagaimana firman Allah dalam surat Al-Baqarah ayat 282:

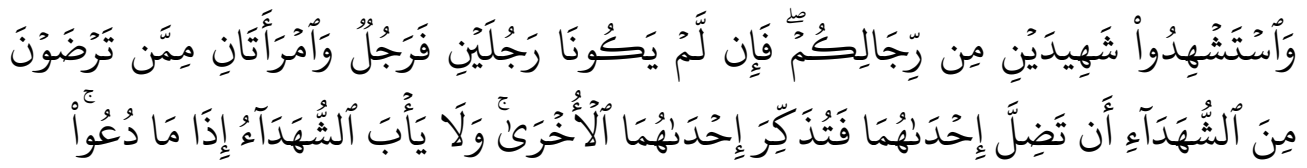

Dan persaksikanlah dengan dua orang saksi dari orang-orang lelaki (di antaramu). jika tak ada dua oang lelaki, Maka (boleh) seorang lelaki dan dua orang perempuan dari saksi-saksi yang kamu ridhai, supaya jika seorang lupa Maka yang seorang mengingatkannya. janganlah saksisaksi itu enggan (memberi keterangan) apabila mereka dipanggil...." (Q.S. Al-Baqarah, 2:282).

2) Berakal sehat, walaupun terkadang terang ingatannya. Persaksian orang gila atau orang kurang akal tidak bisa diterima kesaksiannya.

3) Islam, oleh sebab itu tidak diperbolehkan kesaksian orang kafir atas orang muslim, kecuali dalam hal wasiat di tengah perjalanan. Tapi orang-orang Hanafiyah memperbolehkan kesaksian orang-orang kafir terhadap sesamanya. Saksi non muslim dapat diterima sepanjang penyaksiannya menyangkut peristiwa atau kejadian untuk memperjelas duduk perkaranya (Yahya Harahap, 2008:254).

4) Mengetahui apa yang dipersaksikan, dalam hukum Islam seorang tidak boleh memberikan kesaksian, kecuali kesaksiannya didasarkan pada ilmu, yaitu didasarkan pada sesuatu yang meyakinkan. Orang yang boleh memberikan kesaksian adalah dia yang menyaksikan langsung suatu peristiwa atau hal, baik dengan melihat, mendengar maupun mengalami sendiri. Kesaksian tidak sah jika didasarkan pada zhan (keraguan).

5) Dapat berbicara, karena jika bisu kesaksiannya tidak dapat diterima sekalipun dia dapat mengungkapkan dengan isyarat dan isyaratnya dapat dipahami, kecuali jika dia menulis kesaksiannya itu dengan tulisan menurut Abu Hanifah, Ahmad dan pendapat yang sah dari madzhab Syafi'i.

6) Adil, sifat keadilan merupakan tambahan bagi sifat Islam. Sebagaimana firman Allah dalam surat ath-Thalaq ayat 2: 


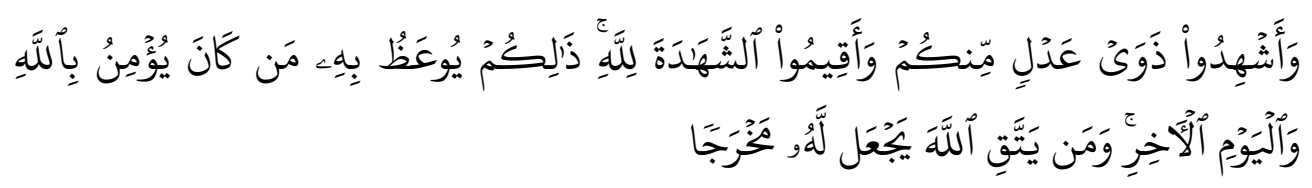

Dan persaksikanlah dengan dua orang saksi yang adil di antara kamu dan hendaklah kamu tegakkan kesaksian itu karena Allah....." (Q.S. AthThalaq, 65:2).

Ibnu Rusyd menambahkan bahwa seorang saksi harus merdeka dan tidak diragukan i'tikad baiknya. Sayyid Sabiq menambahkan bahwa seorang saksi harus memiliki ingatan yang baik dan bebas dari tuduhan negatif (tidak ada permusuhan).

Persaksian orang yang mudah lupa tidak dapat diterima, demikian pula orang yang sudah diketahui orang banyak bahwa dirinya itu banyak lupa dan banyak salah karena kepercayaan tidak dapat muncul dengan kata-kata darinya. Juga tidak menjadi anggapan yang kuat bahwa ia jujur karena adanya kemungkinan ketidakjujuran disebabkan sering melakukan kesalahan. Persaksian dapat diterima dari orang yang sedikit lupa dan salah.

Menurut Hukum Positif, supaya saksi-saksi yang diajukan oleh para pihak dapat didengar sebagai alat bukti, maka harus memenuhi syaratsyarat formil dan materiil. Syarat formil saksi adalah:

1) Memberikan keterangan di depan persidangan.

2) Bukan orang-orang yang dilarang untuk didengar sebagai saksi bagi kelompok yang berhak mengundurkan diri sebagai saksi menyatakan kesediaannya untuk diperiksa sebagai saksi.

3) Mengangkat sumpah menurut Agama yang dianutnya (Pasal 147 HIR)

4) Cakap menjadi saksi.

5) Diperiksa satu per satu.

6) Berumur 15 tahun ke atas.

7) Sehat akalnya.

8) Memberikan keterangan secara lisan, sesuai dengan Pasal 144 ayat (1) HIR.

9) Berjumlah sekurang-kurangnya 2 orang untuk kesaksian suatu peristiwa, atau dikuatkan dengan alat bukti lain, sebagaimana Pasal 169 HIR, kecuali mengenai perzinahan (Mukti Arto, 2005:165-166).

Dalam pasal 169 HIR, Pasal 306 R,Bg dan Pasal 1905 KUH Perdata dijelaskan bahwa keterangan seorang saksi saja tanpa alat bukti lainnya tidak dianggap sebagai pembuktian yang cukup sebagaimana istilah hukum seorang saksibukan saksi (unus testis, nulus testis). Keterangan seorang saksi 
jika tidak ada bukti lainnya maka tidak boleh dipergunakan oleh hakim sebagai alat bukti. Kesaksian dari seorang saksi, tidak boleh dianggap sebagai persaksian yang sempurna oleh hakim, dalam memutus suatu perkara. Hakim dapat membebani sumpah pada salah satu pihak, jika pihak itu hanya mengajukan seorang saksi dan tidak ada alat bukti lainnya.

Sedangkan syarat materiil saksi adalah:

1) Keterangan yang diberikan mengenai peristiwa yang dialami, didengar dan dilihat sendiri oleh saksi (Pasal 171 HIR/ Pasal 308 R.Bg)

2) Keterangan yang diberikan harus mempunyai sumber pengetahuan yang jelas, berdasarkan Pasal 171 ayat (1) dan Pasal 308 ayat (1) R.Bg

3) Keterangan yang diberikan saksi harus bersesuaian satu sama lain atau alat bukti yang sah sebagaimana dijelaskan dalam Pasal 172 HIR dan Pasal 309 R.Bg (Abdul Manan, 2006:250-251).

4) Bukan merupakan pendapat atau kesimpulan saksi sendiri, Pasal 171 ayat (2) dan Pasal 308 ayat (2) R.Bg

5) Tidak bertentangan dengan akal sehat.

Tentang benar tidaknya keterangan orang yang mewajibkan menyimpan rahasia itu terserah pada pertimbangan hakim, sebagaimana Pasal 146 ayat (2) HIR. Orang yang tidak berhak mengundurkan diri sebagai saksi, ia wajib memenuhi kewajiban sebagai saksi.

Adapun orang-orang yang dapat mengundurkan diri dari kewajiban menjadi saksi adalah:

1) Saudara laki-laki dan saudara perempuan, ipar laki-laki dan ipar perempuan dari salah satu pihak.

2) Keluarga sedarah menurut keturunan yang lurus dan saudara laki-laki dan saudara perempuan dari suami atau istri dari salah satu pihak.

3) Semua orang yang karena kedudukannya, pekerjaan atau jabatannya yang sah, diwajibkan menyimpan rahasia, tetapi semata-mata hanya mengenai hal demikian yang dipercayakan padanya, Pasal 146 ayat (1) HIR (Mukti Arto, 2005:166).

Menjadi saksi merupakan kewajiban hukum atas setiap orang. Pasal 224 KUHP menyatakan bahwa "Barang siapa dipanggil sebagai saksi, solusi ahli atau juru bahasa menurut undang-undang dengan sengaja tidak memenuhi suatu kewajiban yang menurut undang-undang selaku demikian harus dipenuhi, diancam: dalam perkara pidana, dengan pidana penjara paling lama sembilan bulan dan dalam perkara lain, dengan pidana penjara paling lama enam bulan" (Moeljatno, 2008:89). 
Pada prinsipnya setiap orang wajib menjadi saksi.Namun demikian untuk memelihara obyektifitas saksi dan kejujuran saksi, ada orang-orang tertentu yang oleh Undang-Undang tidak boleh didengar sebagai saksi sebagai dasar untuk memutus perkara, karena adanya hubungan tertentu dengan para pihak, atau karena keadaan tertentu. Orang yang tidak boleh didengar sebagai saksi ialah:

1) Keluarga sedarah dan keluarga semenda dari salah satu pihak menurut keturunan yang lurus.

2) Istri atau suami dari salah satu pihak, meskipun sudah bercerai.

3) Anak-anak yang tidak diketahui benar apakah sudah cukup umurnya 15 tahun.

4) Orang gila, meskipun ia kadang-kadang mempunyai ingatan terang.

5) Orang yang ada hubungan kerja dengan salah satu pihak dengan menerima upah.

Akan tetapi kaum keluarga sedarah dan keluarga semenda tidak dapat ditolak sebagai saksi dalam perkara perselisihan kedua belah pihak tentang status menurut hukum perdata, tentang perjanjian kerja atau tentang perceraian karena adanya perselisihan suami istri (Mukti Arto, 2005:167).

Berdasarkan Pasal 76 Undang-Undang No. 7 Tahun 1989 tentang Peradilan Agama, dalam perkara perceraian berdasarkan alasan cekcok terus menerus (syiqaq) diperkenankan mempergunakan saksi dari keluarga. Hal ini merupakan Lex Spesialis dari ketentuan umum.

Dalam hal menimbang harga kesaksian hakim harus menumpahkan perhatian sepenuhnya tentang permufakatan dari saksi-saksi, cocoknya kesaksian-kesaksian dari yang diketahui dari tempat lain tentang perkara yang diperselisihkan, tentang sebab-sebab yang mungkin ada pada saksi itu untuk menerangkan dengan cara begini atau begitu, tentang perilaku atau adat dan kedudukan saksi, dan pada umumnya segala hal yang dapat menyebabkan saksi itu dapat dipercaya atau tidak, Pasal 172 HIR. Penggolongan kesaksian:

1) Testimonium de auditu (Pasal 145 ayat (4) HIR), artinya kesaksian yang diperoleh secara tidak langsung dengan melihat, mendengar dan mengalami sendiri melainkan melalui orang lain. Dalam bahasa fiqih disebut saksi istifadhoh yang nilai pembuktiannya tidak perlu dipertimbangkan. Tidak dapat digunakan sebagai bukti langsung, tetapi penggunaan kesaksian yang bersangkutan sebagai persangkaan yang dari persangkaan itu dibuktikan sesuatu, tidaklah dilarang (Hari Sasangka dan Ahmad Rifai, 2005:115). 
2) Kesaksian di luar sumpah (Pasal 145 ayat (4) HIR), anak-anak di bawah umur 15 tahun, saksi yang masih ada hubungan keluarga atau hubungan perkawinan, atau hubungan kerja dengan menerima upah dan orang gila yang kadang-kadang ingatannya terang dapat didengar keterangannya di luar sumpah. Tetapi keterangan mereka semata-mata hanya dipandang sebagai penjelas, sehingga tidak dapat dijadikan dasar hukum untuk memutus perkara.

3) Saksi keluarga (Pasal 145 ayat (2) HIR, Pasal 76 ayat (1) UU No. 7 Tahun 1989 dan Pasal 22 PP No. 9 Tahun 1975). Dapat didengar sebagai saksi di bawah sumpah dalam perkara tentang perselisihan keadaan menurut hukum perdata dan tentang perjanjian, serta tentang perkara perceraian karena alasan perselisihan dan pertengkaran yang terus menerus.

4) Unus testis nulus testis (Pasal 169 HIR/ 306 R.Bg/ 1905 BW), artinya keterangan seorang saksi saja tanpa alat bukti lainnya tidak dianggap sebagai pembuktian yang cukup, seorang saksi bukan saksi, kekuatan pembuktian dari kesaksian seorang saksi saja tidak boleh dianggap sebagai sempurna oleh hakim. Gugatan harus ditolak apabila penggugat dalam mempertahankan dalilnya hanya mengajukan seorang saksi tanpa alat bukti lain (Anshoruddin, 2004:85).

\section{METODE PENELITIAN}

Sesuai dengan karakteristik masalah, tujuan dan kerangka pemikiran yang diteliti serta menggunakan pendekatan penelitian yang digunakan (kualitatif), maka metode yang digunakan dalam penelitian ini adalah metode deskriptif yaitu suatu metode yang bertujuan untuk melukiskan secara sistematis fakta atau karakteristik permasalahan tertentu secara faktual dan cermat, yang diarahkan untuk memecahkan masalah yang terjadi pada saat ini, dan dengan cara memaparkan hasil penelitian apa adanya.

Dengan menggunakan metode ini, penulis berusaha memaparkan kesaksian non muslim perspektif hukum Islam dan hukum Positif serta pertimbangan hukum yang diambil oleh Hakim Pengadilan Agama Bandung tentang kesaksian non muslim melalui data yang telah ada, kemudian hasil deskriptif tersebut dianalisis agar memperoleh suatu kejelasan terhadap masalah kesaksian non muslim dalam pemeriksaan sidang perkara perceraian di Pengadilan Agama Bandung menurut hukum Islam dan hukum perdata. 


\section{HASIL DAN PEMBAHASAN}

Pengadilan Agama Bandung berdiri kurang lebih pada tahun 1882. Ada dua hal yang kiranya dapat dijadikan suatu sandaran atau Asumsi atas didirikannya Pengadilan Agama Bandung, yang ini didasarkan atas: (a) Bandung sebagai wilayah administratif; dan (b) berdirinya Pengadilan Agama Jawa Madura

Dari sejak berdirinya hingga pasca kemerdekaan, yakni tepatnya pada tahun 1972 Pengadilan Agama Bandung beralamat di komplek Masjid Agung di Jalan Dalem Kaum dengan dipimpin oleh seorang Penghulu Recht yang disebut Hup Penghulu atau Kepala Penghulu atau yang dikenal sekarang sebagai Ketua Pengadilan Agama (www.pa-bandung.go.id).

Sampai dengan pertengahan tahun 1972, Pengadilan Agama Bandung masih berkantor di komplek Masjid Agung di Dalem Kaum yang secara umum memiliki kekuatan tenaga pegawai Pengadilan Agama sebanyak 9 orang, yang terdiri dari 1 orang Ketua merangkap sebagai Hakim Ketua, 1 orang Wakil Ketua, 2 orang Hakim Anggota Tetap, 1 orang Panitera, 1 orang Jurutulis (tenaga administrasi), dan sisanya sebagai pesuruh (www.pabandung.go.id// page/content/149).

Kemudian pada tanggal 12 Juli 1972 kantor Pengadilan Agama Bandung dipindahkan ke Jalan Garuda menjadi satu dengan kantor penerangan Agama Islam Provinsi Jawa Barat (sekarang menjadi Kantor Wilayah Departemen Agama Provinsi Jawa Barat) alasan kepindahan tersebut karena kantor itu akan dibongkar dalam rangka peluasan Masjid Agung (www.pa-bandung.go.id//page/content/149)

Di jalan Garuda, Pengadilan Agama Bandung hanya menempati beberapa lokal saja, sehingga volume kerja yang dihadapi, dirasa kurang memadai. Pada tahun 1976/1977 Pengadilan Agama Bandung mulai menerima pegawai negeri sipil guna meningkatkan sumber daya manusia dan juga di saat seluruh Pengadilan Agama mendapat Daftar Isian Proyek (DIP), maka dibangunlah gedung yang nantinya akan dipergunakan sebagai kantor atau balai sidang yang lebih representatif, tidak menumpang dan tidak berpindah-pindah lagi (www.pa-bandung.go.id//page/content/149).

Dan pada tahun 1976 untuk wilayah hukum Bandung Raya memiliki 2 Pengadilan Agama, yaitu Pengadilan Agama Bandung dan Pengadilan Agama Cimahi. Kemudian pada tanggal 1 April 1978, Pengadilan Agama Bandung resmi menempati bangunan baru yang berdiri di atas tanah seluas 600 m2, dengan Hak Sewa Guna Pakai dari Pemerintah Kota Bandung, yang sampai akhir tahun 2007 setelah melakukan peluasan bangunan gedung kantor Pengadilan Agama Bandung mencapai 500 m2 yang terletak di jalan Tangkuban Parahu No. 14 sekarang dikenal Jalan Pelajar Pejuang 45 No. 8 Bandung (www.pa-bandung.go.id//page/content/149). 
Seiring dengan berjalannya waktu, pada tanggal 11 Februari 2008 Bapak Ketua Mahkamah Agung Republik Indonesia, Bapak Bagir Manan meresmikan Gedung kantor Pengadilan Agama Bandung yang baru, yang terletak di jalan Terusan Jakarta No. 120 Antapani Kota Bandung, yang sampai sekarang masih digunakan.

Dalam penelitian ini, penulis mewawancarai dua hakim Pengadilan Agama Bandung yang telah ditunjuk oleh Wakil Ketua Pengadilan Agama Bandung untuk memberikan informasi kepada penulis terhadap penulisan penelitian dengan judul "Kesaksian Non Muslim dalam Perkara Perceraian Menurut Pendapat Hakim di Pengadilan Agama Bandung".

\section{Analisis Terhadap Kesaksian Non Muslim Dalam Perkara Perceraian Menurut Pendapat Hakim Pengadilan Agama Bandung}

Pada dasarnya asas keislaman adalah asas utama yang melekat pada Undang-Undang peradilan agama yang mempunyai makna bahwa pihak yang tunduk dan dapat ditundukkan kepada kekuasaan di lingkungan peradilan agama hanya karena yang beragama Islam. Keislaman seseoranglah yang menjadi dasar kewenangan pengadilan agama di lingkungan peradilan agama. Dengan kata lain, seorang penganut agama non Islam tidak tunduk dan tidak dapat dipaksakan tunduk kepada kekuasaan peradilan agama. Asas ini diatur dalam Pasal 2, Penjelasan Umum angka 2 alinea ketiga dan Pasal 49 ayat (1) Undang-Undang Nomor 3 Tahun 2006. Penegasan asas personalitas dapat dianalisis sebagai berikut:

1) Menunjuk pada para pihak yang berperkara ataupun yang menjadi bagian dalam penyelesaian perkara harus beragama Islam, jika salah satu pihak atau yang menjadi bagian dalam perkara tersebut tidak beragama Islam, maka perkaranya tidak dapat ditundukkan kepada kewenangan pengadilan di lingkungan peradilan agama.

2) Menunjuk pada hukum yang melandasi hubungan hukum tersebut. Dalam hal ini haruslah hukum Islam, jika hubungan hukum yang telah mendasarinya yaitu hukum Islam, maka perkara tersebut tidak menjadi kewenangan pengadilan agama.

Pengertian saksi yang diberikan oleh bapak Enas Nasruddin dan bapak Kamaluddin tidak berbeda jauh hanya saja bapak Enas Nasruddin memberikan keterangan bahwa orang yang bersaksi di depan persidangan harus memenuhi syarat-syarat tertentu. Yang dimaksud syarat-syarat tertentu yang harus dipenuhi adalah syarat materiil dan syarat formil saksi. Tanpa terpenuhinya syarat-syarat tersebut seseorang tidak bisa dijadikan saksi sebuah perkara di depan persidangan.

Pembuktian dengan saksi-saksi diperbolehkan dalam segala hal, kecuali jika Undang-Undang menentukan lain. Pembuktian dengan saksisaksi baru dibutuhkan jika alat bukti surat atau tulisan tidak ada atau 
kurang lengkap untuk mendukung dan menguatkan dalil-dalil yang menjadi dasar pendirian para pihak.

Adapun pengertian kesaksian menurut bapak Enas Nasruddin adalah:

"Keterangan saksi yang diberikan di dalam persidangan untuk meyakinkan Majelis Hakim bahwa peristiwa atau sengketa yang terjadi di antara para pihak betul-betul terjadi" (Enas Nasruddin, Wawancara).

Sedangkan pengertian kesaksian menurut bapak Kamaluddin:

"Menyaksikan kejadian atau peristiwa yang terjadi dengan mata kepala sendiri dan bukan dari orang lain" (Kamaluddin, Wawancara).

Keterangan bapak Kamaluddin dapat diartikan bahwa orang yang menjadi saksi adalah orang yang mengetahui betul kejadian atau peristiwa, dan pengetahuannya itu didapatkan dari penglihatan atau pendengarannya sendiri, bukan dari orang lain, maka dengan menyaksikan sendiri ia bisa didengar sebagai saksi yang memberikan keterangan di depan persidangan. Walaupun pengertian kedua responden berbeda tapi pada intinya sama, yaitu kesaksian merupakan keterangan yang diberikan oleh saksi yang bertujuan untuk meyakinkan hakim mengenai sebuah kejadian, yang mana pengetahuannya tersebut diketahuinya sendiri bukan dari orang lain.

Keterangan saksi yang dapat meyakinkan hakim apabila ia peroleh dari penglihatanya, mengalaminya dan mendengarnya sendiri, sebagaimana menurut kaidah Ushul Fiqih yang disebut dengan yakin:

$$
\text { هو ما كان ثابتا با لنظر و الدليل }
$$

Sesuatu yang tetap, dengan karena penglihatan atau dengan adanya dalil (bukti)" (Kamaluddin, Wawancara).

Dengan penglihatan maka sudah tentu saksi mendengar dan ikut mengalami sebuah peristiwa, sehingga dengan itu ia bisa meyakinkan hakim. Dengan begitu sebuah keyakinan dapat dimunculkan ketika saksi mengatakan bahwa keterangan yang ia berikan karena ia mengalaminya, mendengarnya dan melihatnya sendiri.

Kesaksian atau keterangan yang diberikan oleh saksi baru bisa dianggap sebagai alat bukti dan bisa digunakan sebagai bahan pertimbangan oleh hakim jika saksi memberikan keterangannya di depan sidang pengadilan dan berada di bawah sumpah. Karena fungsi saksi adalah:

Untuk meneguhkan dalil-dalil gugatan Penggugat atau Pemohon atau bantahan Tergugat atau Termohon. Di Pengadilan Agama Bandung alat bukti yang biasa digunakan adalah alat bukti tertulis, saksi dan pengakuan, sedangkan dalam pembuktian yang paling sering digunakan 
oleh para pihak adalah alat bukti tertulis dan alat bukti saksi sedangkan alat bukti pengakuan jarang dipakai" (Enas Nasruddin, Wawancara).

Selain itu fungsi saksi menurut bapak Kamaluddin adalah:

Sebagai tambahan untuk menguatkan dalil penggugat.Karena jika apa yang dikatakan Penggugat dan saksi berbeda, maka dalil-dalil yang diajukan penggugat bisa ditolak oleh Majelis Hakim" (Kamaluddin, Wawancara).

Dalam masalah persaksian yang terpenting adalah saksi tersebut dapat mengungkapkan kebenaran dengan cara memberikan keterangan yang sebenarnya kepada majelis hakim guna membantu hakim dalam memutuskan perkara dengan seadil-adilnya, dengan begitu saksi non muslim pun ada yang dapat dijamin kepercayaanya sehingga kesaksiannya dapat dijadikan landasan dan dapat diterima sebagai alat bukti.

Saksi dalam perkara perceraian di Pengadilan Agama Bandung adalah sebagai alat pembuktian berhubungan dengan syarat formal yang bersifat qadhaan yaitu guna memperjelas suatu peristiwa dan kejadian yang dipersengketakan oleh pihak yang berperkara sehingga jika saksi tersebut telah memenuhi syarat formal maka dapat diterima sebagai alat bukti.

Berdasarkan uraian di atas, bahwa Hakim Pengadilan Agama Bandung dalam menyelesaikan perkara perceraian yang menggunakan saksi non muslim pada prinsipnya tidak dapat menerima kesaksian saksi non muslim sebagai alat bukti, tetapi tidak secara mutlak, karena secara kasuistik dapat menerima kesaksian saksi non muslim sebagai alat bukti karena alasan-alasan tertentu.

Dalam hal ini sesuai dengan Pasal 54 Undang-Undang Nomor 7 Tahun 1989 yaitu yang berbunyi sebagai berikut:

“Hukum acara yang berlaku pada Pengadilan dalam lingkungan Peradilan Agama adalah hukum acara Perdata yang berlaku pada Pengadilan dalam lingkungan Peradilan Umum, kecuali yang telah diatur secara khusus dalam Undang-Undang ini".

Hukum Acara Perdata yang diterapkan dan diberlakukan di Pengadilan Agama Bandung sudah sesuai dengan perundang-undangan yang berlaku yaitu HIR, sedangkan hukum acara khusus yang diterapkan adalah:

1) Undang-Undang Nomor 7 Tahun 1989.

2) Undang-Undang Nomor 1 Tahun 1974 jo Peraturan Pemerintah Nomor 9 Tahun 1975.

3) Inpres Nomor 1 Tahun 1991 (Kompilasi Hukum Islam). 
4) Peraturan dan Surat Edaran Mahkamah Agung RI.

5) Peraturan dan Keputusan Menteri Agama.

6) Kitab Fiqih dan Sumber Hukum Islam.

Dasar Hukum Kesaksian Non Muslim Dalam Perkara Perceraian Menurut Pendapat Hakim Pengadilan Agama Bandung

Dasar Hukum uraian di bawah ini adalah Pasal 1905, 1906 dan 1907 KUH Perdata:

a. Alat Bukti Yang Memenuhi Syarat Formil

1) Orang yang tidak dilarang sebagai saksi berdasarkan Pasal 1910 KUH Perdata, Pasal 145 Jo. Pasal 172 HIR;

2) Memberi keterangan di persidangan sesuai dengan ketentuan Pasal 144 HIR dan Pasal 1905 KUH Perdata;

3) Mengucapkan sumpah menurut agama atau keyakinan berdasarkan Pasal 1907 KUH Perdata dan Pasal 171 HIR.

b. Alat Bukti Yang Memenuhi Syarat Materiil

1) Keterangan yang diberikan didukung oleh alasan dan pengetahuan yang jelas sesuai ketentuan Pasal 1907 KUH Perdata dan Pasal 171 HIR;

2) Fakta peristiwa yang diterangkan bersumber dari pengalaman, penglihatan, dan mendengar sendiri tentang hal yang benar-benar berkaitan langsung dengan perkara yang disengketakan sesuai pasal 1907 KUH Perdata dan Pasal 171 HIR;

3) Keterangan yang diberikan saling bersesuaian antara yang satu dengan yang lain atau dengan alat bukti lain berdasarkan Pasal 1906 KUH Perdata dan Pasal 170 HIR.

i. Pasal 1905: "Keterangan seorang saksi saja tanpa alat pembuktian lain, dalam Pengadilan tidak boleh dipercaya".

ii. Pasal 1906: "Jika kesaksian-kesaksian berbagai orang mengenai berbagai peristiwa terlepas satu sama lain, dan masing-masing berdiri sendiri, namun menguatkan suatu peristiwa tertentu karena mempunyai kesesuaian dan hubungan satu sama lain, maka hakim, menurut keadaan, bebas untuk memberikan kekuatan pembuktian kepada kesaksian-kesaksian yang berdiri sendiri itu.

iii. Pasal 1907: “tiap kesaksian harus disertai keterangan tentang bagaimana saksi mengetahui kesaksiannya. Pendapat maupun dugaan khusus, yang diperoleh dengan memakai pikiran, bukanlah suatu kesaksian. 
Dasar hukum menggunakan saksi dalam perkara perceraian:

1) Firman Allah Surat Al-Baqarah ayat 282, “Dan persaksikanlah dengan dua orang saksi dari orang-orang lelaki (di antaramu). jika tak ada dua oang lelaki, Maka (boleh) seorang lelaki dan dua orang perempuan dari saksi-saksi yang kamu ridhai, supaya jika seorang lupa Maka yang seorang mengingatkannya. janganlah saksi-saksi itu enggan (memberi keterangan) apabila mereka dipanggil" (Q.S. Al-Baqarah, 2:282)

2) Firman Allah dalam Surat Al-Maidah ayat 106, "Hai orang-orang yang beriman, apabila salah seorang kamu menghadapi kematian, sedang Dia akan berwasiat, Maka hendaklah (wasiat itu) disaksikan oleh dua orang yang adil di antara kamu, atau dua orang yang berlainan agama dengan kamu" (Q.S. Al-Maidah, 5:106)

Pertimbangan Hukum Kesaksian Non Muslim Dalam Perkara Perceraian Menurut Pendapat Hakim Pengadilan Agama Bandung

Dalam Undang-Undang Hukum Acara Perdata tidak ditentukan Kriteria beragama Islam bagi saksi, tapi hanya syarat formil dam materiilnya saja.Syarat formil dan syarat materiil yang ditetapkan oleh Undang-Undang tentu memiliki tujuan.Salah satu tujuan seperti saksi harus mengucapkan sumpah adalah untuk mencari kebenaran dari keterangan saksi dan dengan sumpah saksi diharapkan akan berkata yang sejujurnya.

Para ulama menetapkan kriteria seorang saksi yaitu harus beragama Islam, tetapi di Pengadilan Agama Bandung hakim tidak menggunakan semua kriteria dari ulama sebagai pedoman dalam menentukan seorang saksi di depan persidangan harus beragama Islam. bahwa:

Sebagaimana Pendapat Bapak Enas Nasrudin yang mengatakan

"Kita sebagai rakyat Republik Indonesia yang mana penduduk yang berada di Indonesia itu tidak semuanya beragama Islam, dan sekarang umat Islam tidak hanya berinteraksi dengan orang-orang Islam saja tapi juga berinteraksi langsung dengan orang-orang non Islam, sehingga untuk mencari kriteria-kriteria seperti yang diungkapkan oleh para Ulama tentu kurang memungkinkan. Bisa saja ketika terjadi suatu perselisihan ataupun pertengkaran antara penggugat dan tergugat yang beragama Islam ternyata disaksikan dan diketahui oleh orang non Muslim, sehingga ketika orang tersebut dihadirkan di depan persidangan sudah jelas ia tidak memenuhi semua kriteria-kriteria tersebut" (Enas Nasrudin, Wawancara).

Hukum Islam adalah hukum yang elastik, hukum Islam selau mengikuti perkembangan zaman. Hukum Islam di Indonesia tidak bisa diterapkan sepenuhnya seperti pada bangsa Arab zaman dahulu ketika 
Nabi Muhammad SAW masih ada. Jika seumpamanya hukum Islam tidak mengikuti perkembangan zaman dan harus dianut dengan fanatik seperti dahulu bisa jadi hukum Islam akan dilupakan.

Sekalipun itu di Pengadilan Agama sendiri yang notabene berbasis Islam dan salah satu hukum materiilnya menggunakan Al-Quran dan Hadits. Jika Pengadilan Agama tetap mempertahankan apa yang tersurat dalam Al-Quran maupun Hadits tanpa ditelaah dengan baik, yang diperkirakan bisa atau tidak diterapkan pada zaman sekarang, tentunya tidak aka nada orang yang mau berperkara di Pengadilan Agama.

\section{KESIMPULAN}

Adapun kesimpulan dari penelitian ini sebagaimana penulis uraikan di atas, dapat dipaparkan sebagai berikut: (1) Menurut pendapat hakim Pengadilan Agama Bandung, kesaksian non muslim dalam perkara perceraian dapat diterima dan dinyatakan sah sebagai saksi yang memberikan keterangan di depan persidangan, karena Pengadilan Agama Bandung tidak membedakan antara saksi non muslim dan saksi muslim. Yang terpenting dalam kesaksiannya itu telah memenuhi syarat materiil dan formil. (2) Dasar hukum yang digunakan hakim Pengadilan Agama Bandung adalah Pasal $164 \mathrm{HIR} / 284 \mathrm{RBg} / 1866 \mathrm{KUH}$ Perdata adalah surat, saksi, persangkaan, pengakuan, sumpah. Kemudian Pasal-Pasal yang berhubungan dengan masalah saksi adalah Pasal 144 HIR, Pasal 170 HIR dan Pasal 171 HIR. Pertimbangan hukum Hakim Pengadilan Agama Bandung terhadap kesaksian non muslim dalam perkara perceraian adalah saksi non muslim tersebut dapat diterima kesaksiannya sebagai alat bukti dalam perkara perceraian karena saksi tersebut telah memenuhi syarat formil dan materiil, dan juga mempertimbangkan interaksi masyarakat Indonesia itu telah bercampur antara umat Islam dan non muslim, jadi apabila ada seseorang yang sedang berselisih dalam rumah tangga, kemudian yang menyaksikan langsung kejadian itu non muslim, kita tidak bisa memaksakan harus membawa saksi muslim, karena di Pengadilan Agama Bandung itu mencari kebenaran yang formil.

\section{DAFTAR PUSTAKA}

Al-Faruq, Asadulloh. (2009). Hukum Acara Peradilan Islam. Jakarta: PT. Buku Kita.

Anonimous, (2004). Al- Quran Dan Terjemah. Bandung: Al-Jumanatul 'Ali.

Anonimous. (2007). Kompilasi Hukum Islam Indonesia dan Undang-Undang Republik Indnesia Nomor 1 Tahun 1974 tentang Perkawinan. Trinity, t.k. 
Anshoruddin. (2004). Hukum Pembuktian Menurut Hukum Acara Islam dan Hukum Positif. Cet ke-1, Yogyakarta: Pustaka Pelajar Offset.

Arto, Mukti. (2005). Praktek Perkara Perdata Pada Pengadilan Agama. Cet ke-6, Yogyakarta: Pustaka Pelajar.

Aunullah, Indi. (2008). Ensiklopedi Fikih Untuk Remaja. Jilid 2, Yogyakarta: Pustaka Insan Madani.

Harahap, Yahya. (2008). Hukum Acara Perdata.Cet ke-12, Jakarta: Sinar Grafika.

Hasan Bisri, Cik. (1997). Peradilan Islam Dalam Tatanan Masyarakat Indonesia. Bandung: PT. Remaja Rosdakarya.

Manan, Abdul. (2006). Penerapan Hukum Acara Perdata di Lingkungan Peradilan Agama. Jakarta: Kencana.

Mansyur Syah, Umar. (1991). Hukum Acara Perdata Peradilan Agama Menurut Teori dan Praktek. Garut: Yayasan Al-Umaro.

Mertokusumo, Sudikno. (1993). Hukum Acara Perdata Indonesia. Yogyakarta: Liberty.

Moeljatno. (2008). Kitab Undang-Undang Hukum Pidana. Cet ke-7, Jakarta: Sinar Grafika Offset.

Muhammad Zainal Abidin, "Alat Bukti Dalam Pengadilan Agama "http://meetabied.wordpress.com/2009/10/29/alat-bukti-dalam-pengadilanagama/, (Diakses pada 25 Mei 2016).

R. Subekti, R. Tjitrosudibio. (2008). Kitab Undang-Undang Hukum Perdata. Cet ke-38, Jakarta: PT. Pradaya Paramita.

R. Tresna. (2005). Komentar Herziene Inlandsch Reglement (HIR). Jakarta: PT. Pradaya Paramita.

Rasyid, Chatib dan Syaifuddin. (2009). Hukum Acara Perdata Dalam Teori dan Praktik Pada Peradilan Agama. Yogyakarta: UII Press.

Rasyid, Raihan. (2001). Hukum Acara Peradilan Agama. Cet ke-8, Jakarta: PT. Raja Grafindo Persada.

Rasyid, Sulaiman. (2000). Fikih Islam. Bandung: PT. Sinar Baru Algensindo.

Sabiq, Sayyid. (1989). Fikih Sunnah. Jilid 14, Bandung: PT. Al-Ma'arif. (1990). Fikih Sunnah. Jilid 9, cet ke-9, Bandung: PT. Al-Ma'arif.

Saleh, K. Wantjik. (1980). Hukum Perkawinan Indonesia. Cet ke-6, Jakarta: Ghalia Indonesia.

Sasangka, Hari. (2005). Hukum Pembuktian dalam Perkara Perdata. Cet ke-1, Bandung: Mandar Maju. 
Soepomo. (1978). Hukum Acara Peradilan Negeri. Jakarta: PT. Pradaya Paramita.

Subekti dan Tjitrosoedibio. (1980). Kamus Hukum. Cet ke-5, Jakarta: PT. Pradaya Paramita.

Sugono, Bambang. (2003). Metode Penelitian Hukum. Jakarta: PT. Raja Gaffindo. 